(2) Open Access Full Text Article

ORIGINAL RESEARCH

\title{
Association of Effective Spousal Family Planning Communication with Couples' Modern Contraceptive Use in Harar, Eastern Ethiopia
}

This article was published in the following Dove Press journal: Open Access Journal of Contraception

\section{Desalew Zelalem (D) Alemayehu Worku (D) ${ }^{2}$ Tadese Alemayehu (iD) Yadeta Dessie}

'School of Public Health, College of Health and Medical Sciences, Haramaya University, Harar, Ethiopia; ${ }^{2}$ Department of Epidemiology and Biostatistics, School of Public Health, Addis Ababa University, Addis Ababa, Ethiopia
Correspondence: Desalew Zelalem School of Public Health, College of Health and Medical Sciences, Haramaya University, P.O. Box, 235, Harar, Ethiopia Email desalewzelalemayele@yahoo.com
Background: Spousal family planning communication plays an important role in making better reproductive health decisions and in increasing the use of modern contraceptive methods. The objective of the current study is to examine the association of spousal family planning communication in its broader context with current modern contraceptive use among couples.

Methods: A community based cross-sectional survey was conducted in twelve kebeles of Harar Urban Health and Demographic Surveillance System. A total of 2700 currently married couples of whose wives were in the reproductive age participated in the study. The selection of the study participants was made using simple random sampling and data were collected using an interviewer administered structured questionnaire and analyzed using Stata version 12 .

Results: The level of current modern contraceptive use was $57.1 \%$ (95\% CI: $0.53,3.39$ ). Effective spousal family planning communication was significantly associated with current modern contraceptive use even after controlling for socio-economic and demographic variables. Socio-economic and demographic variables such as religion of couples, number of couples' living children, household monthly income, couples' family planning approval and women's counseling about family planning by health workers were significantly associated with current modern contraceptive use.

Conclusion: Policies and programs aimed at increasing contraceptive prevalence should properly address the importance of spousal communication about family planning and integrate men into family planning programs to facilitate and enhance couples communication skills.

Keywords: effective communication, Poisson regression, Harar Urban HDSS, current contraceptive use

\section{Background}

Spousal family planning communication plays an important role in making better reproductive health decisions, number of children, timing of births, understand advantage and disadvantage of family planning methods, choice of contraceptive methods, and increased contraceptive use. ${ }^{1,2}$ Spousal communication about family planning also enables women to understand about their husbands' attitude towards family planning and hence encouraging contraceptive use. The importance of spousal communication is often emphasized in family planning programs and research. In some researchers' views, it is considered the first step in a rational fertility decision-making process. ${ }^{3}$ 
Literatures have revealed that there is a positive association between spousal communication about family planning and couples contraceptive use. ${ }^{3-5}$ Moreover, the extent and frequency of spousal communication between couples matters in the adoption of modern contraception. ${ }^{6-9}$ Hence, the extent and frequency of communication among couples concerning fertility and family planning appears to be an important determinant and predictor variable of current use of family planning methods. Literature also indicated that a husband's approval of family planning methods and support is a good predictor of future practice and continued use of contraceptives by women. ${ }^{10}$

In Ethiopia, although the level of knowledge and approval of family planning methods is high, ${ }^{11-13}$ the actual use of contraceptive methods is low. This highlights the importance of promoting family planning services by identifying the barriers to avert the adverse consequences incurred by Ethiopian women and children. There are many studies in Ethiopia which focused on identifying the socioeconomic, cultural and demographic factors that influence the use of modern contraceptive methods. ${ }^{14-16}$ But the role of husband-wife communication on family planning, particularly the role of spousal family planning communication in its broader context, has been given little attention by family planning studies.

There are some studies which tried to assess the association between spousal family planning communication and couples' contraceptive adoption ${ }^{11,17,18}$ and these studies revealed that spousal communication promotes contraceptive use. However, methodologically, these studies depended on the narrow definition of communication which takes spousal family planning discussion as the only measure of communication. Practically, however, effective spousal family planning communication should be measured using the broader definition involving the three dimensions of spousal family planning communication, i.e., discussion between husband and wife about family planning, agreement between partners regarding approval of family planning and fertility preferences and each spouse's perceptions of the attitudes of his or her partner ${ }^{19}$ towards family planning to give a comprehensive picture of communication and relate it with contraceptive use. Moreover, studies that collect couple's data are rare in Ethiopia. Thus, the current study examines the association of spousal family planning communication in its broader context with current modern contraceptive use among couples using data collected from both husband and wife.

\section{Methods}

\section{Study Setting}

This study was conducted in Harar Urban Health and Demographic Surveillance System (Harar Urban HDSS) which is located in Harar town, Harari region, Eastern Ethiopia. Harar town is located at a distance of $510 \mathrm{~km}$ from Addis Ababa, the national capital and it is the capital city of the Harari region. The region is boarded with different districts of the Eastern Hararghe zone of Oromiya regional state and divided in to 36 kebeles (19 urban and 17 rural kebeles). ${ }^{20}$ According to the 2013 population projection, the total population of the region for the year 2017 was estimated at 244,711 of which $49.5 \%$ were females and $55.7 \%$ were urban dwellers. ${ }^{21}$

Originally Harar Urban HDSS was established in Harar town to represent the Eastern part of Ethiopia and Harar town was selected among other towns in the Eastern part of Ethiopia due to the diversity of its population in ethnicity (there are around 50 ethnic groups in the town) and diversity in terms of religious affiliation of the population. ${ }^{22}$ Moreover, 12 out of 19 kebeles (subdistricts, smallest administrative unit in Ethiopia) in the town are included in Harar Urban HDSS.

In 2013 the total population of Harar Urban HDSS was 30,055 (52.2\% females and $47.8 \%$ males) and the sex ratio was $91.4 \%$. Crude birth rate was 20.3 births per 1000 midyear population, general fertility rate was 64 births per 1000 women of reproductive age and total fertility rate was 1.9 births per woman in $2013 .^{23}$

\section{Study Design}

A community based cross sectional study was conducted in Harar Urban Health and Demographic Surveillance System from September 2018 to March 2019.

\section{Source and Study Population}

The source and study populations for this study were all married couples of whose wives were in the reproductive age (15-49 years) and non-pregnant during the data collection period in Harar Urban HDSS.

\section{Sample Size and Sampling}

The sample size was computed using Minitab version 17 statistical software. Including $10 \%$ for non-responses, the final sample resulted in 2874 couples. This sample was distributed among the 12 kebeles according to the proportion of currently married couples whose wives were in the reproductive age and non-pregnant at the survey. All the 
12 kebeles of Harar Urban HDSS were included in the current study. The complete list of currently married couples whose wives were 15-49 years (reproductive age) and non-pregnant was taken from Harar Urban HDSS database and used as a sampling frame. Married couples were then randomly sampled from each kebele, based on a computer generated random number list using the allocated sample size.

\section{Data Collection}

Data was collected using structured questionnaires. Separate questionnaires were administered for male and female respondents but with similar contents including socio-economic and demographic characteristics (age, duration of current marriage, ethnicity, religion, education, occupation, number of living children, desired number of children, household ownership of assets and household income), knowledge/attitude to family planning variables (knowledge of family planning methods, attitude towards family planning, attitude towards large family size and approval of family planning), couples' participation in family planning use decision and their exposure to family planning message through mass media such as radio, television, newspapers, posters, pamphlets, etc and through interpersonal communication with health personnel, friends, relatives, neighbors). And couples' family planning communication and their ever and current modern contraceptive use were also measured.

The survey instruments were adapted from a validated questionnaire and were considered valid and reliable. ${ }^{24}$ Pre-test of questionnaires was done among one percent of the total sample in an area other than the study site, but with a similar set-up. The purpose of the pre-test was to ascertain problems with the data collection tool and make necessary corrections. Twelve male and twelve female data collectors participated in the study and were supervised by two field coordinators. Data collectors were recruited from the local community. The interview was conducted in a private location, each couple at a time (first woman and next man) but separately keeping interviewee privacy. The interview was conducted if both spouses agreed to participate in the study.

\section{Measurements}

Spousal family planning communication was measured based on the question "Have you ever discussed about family planning with your husband/wife in the last 12 months?" Hence, the responses were coded as 1 if both spouses agree they discussed or the husband alone reported ever discussed or the wife alone reported ever discussed and 0 if both spouses agree they never discussed. $^{25}$

Effective spousal family planning communication was measured by taking three variables, i.e., spousal family planning discussion in the last 12 months prior to the survey date; couples' approval or disapproval of family planning and spouses' perceptions about their partner's approval of family planning and couple's fertility desires which were defined through their responses regarding the number of children that each spouse would choose to have for his or her entire reproductive life (ideal family size). Hence, effective communication about family planning among couples exists when couples discuss about family planning in the last 12 months prior to the survey date; when husband's perception to his wife's family planning approval matches with wife's response to family planning approval question and when wife's perception to her husband's family planning approval matches with husband's response to family planning approval question and when responses of couples' to their desired number of children concords. ${ }^{19}$

Current contraceptive use was measured based on the question "Are you currently using any modern contraceptive method to delay (or avoid) having children?". 13 Both husband and wife were asked this question. However, since the number of husbands who were current contraceptive users was negligible (only 60 men or $2.3 \%$ were current contraceptive users), the current analysis of the current contraceptive use depends only on women's response.

\section{Data Analysis}

The data were double entered, validated and cleaned using EpiData Software, version 3.1. The data was analyzed using Stata version 12. Simple descriptive analysis was done to explore levels of contraceptive use. Bivariate analysis was used to investigate the association between socio-economic, demographic, knowledge/attitude to family planning and family planning communication variables and current contraceptive use.

Since logistic regression overestimates the effect measure when the outcome variable is common (greater than $10 \%$ ), ${ }^{26}$ we tried to apply log binomial to estimate relative risk. However, due to the problem of convergence with log binomial, we applied Poisson regression with robust variance for estimating prevalence ratio ${ }^{27}$ and to identify predictors of the outcome variable. Moreover, Poisson regression with robust variance provides better results when the covariates of 
interest are categorical. ${ }^{28}$ It uses a log link function with a Poisson distribution to the data. The model can be written as: $\log \left(\pi_{\mathrm{i}}\right)=\beta_{0}+\beta_{1} \mathrm{x}_{1 \mathrm{i}}+\ldots+\beta_{\mathrm{k}} \mathrm{x}_{\mathrm{ki}}{ }^{29}$ Where $\pi_{\mathrm{i}}$ is the probability of experiencing the outcome of interest for subject $\mathrm{i}$, and $\beta_{1} \mathrm{x}_{1 \mathrm{i}}+\ldots+\beta_{\mathrm{k}} \mathrm{x}_{\mathrm{ki}}$ are predictor variables along with the regression coefficients. Statistical significance was considered at a p-value less than 0.05 .

\section{Ethical Clearance}

This study was conducted according to the principles of the Declaration of Helsinki. Ethical clearance was obtained from the Institutional Health Research Ethics Review Committee of College of Health and Medical Sciences, Haramaya University. To safeguard the autonomy of the study participants, objectives of the research were clearly communicated and an informed, voluntary, written and signed consent was obtained from the study participants prior to the data collection. To maintain anonymity and confidentiality, names of the study participants were not mentioned in the questionnaires. No person had access to the information collected from the study participants except the research team. Privacy of the study participants was maintained during the interview.

\section{Results}

\section{Respondents' Characteristics}

Of the 2874, 2700 couples were included in the study giving a response rate of $93.9 \%$. The major reasons for non-response in this study were: some sampled couples (84 couples) refused to participate in the study and for some others the collected data were not complete (for 90 couples) and discarded from analysis. About $65.6 \%$ women belong to the age group 15 to 34 years with the mean age of 31.1 years and standard deviation of \pm 6.8 years. On the other hand, $65.3 \%$ of men belong to the age group of 35 years and above with mean age of 37.9 years and standard deviation of \pm 8.7 years. More than $50 \%$ of the couples were followers of Christianity in religion. About two-fifth of the study participants were Oromo preceded by Amhara ethnic group. More than 50\% of the women were housewives while more than one-third of the husbands were government employees. More than $80 \%$ women and about $90 \%$ men were primary level and above educated, respectively. About 1423 (57.6\%) couples had one to two children, $730(29.5 \%)$ had three to four children and $318(12.9 \%)$ had five or more children. In terms of number of children desired, 1024 (38.2\%) couples wanted one to four children, 647 (24\%) five or more children, $962(35.9 \%)$ had discordant desires and 50 $(1.9 \%)$ other (Table 1$)$.

Table I Socio-Economic and Demographic Characteristics of Couples, Harar, Eastern Ethiopia, 2019

\begin{tabular}{|c|c|c|c|c|}
\hline \multirow[t]{2}{*}{ Variables } & \multirow{2}{*}{$\begin{array}{l}\text { Women } \\
\text { Frequency }\end{array}$} & \multirow[t]{2}{*}{ Percent } & \multirow{2}{*}{$\begin{array}{l}\text { Men } \\
\text { Frequency }\end{array}$} & \multirow[t]{2}{*}{ Percent } \\
\hline & & & & \\
\hline Age & $(N=2699)$ & & $(N=2699)$ & \\
\hline $15-24$ & 453 & 16.8 & 86 & 3.2 \\
\hline $25-34$ & 1318 & 48.8 & 853 & 31.6 \\
\hline $35+$ & 928 & 34.4 & 1760 & 65.2 \\
\hline Religion & $(N=2695)$ & & $(N=2685)$ & \\
\hline Muslim & 1167 & 43.3 & $|14|$ & 42.5 \\
\hline Christian & 1520 & 56.4 & 1535 & 57.2 \\
\hline Other & 8 & 0.3 & 9 & 0.3 \\
\hline Ethnicity & $(N=2691)$ & & $(N=2687)$ & \\
\hline Oromo & 1087 & 40.4 & 1065 & 39.6 \\
\hline Amhara & 962 & 35.8 & 894 & 33.3 \\
\hline Harari & 60 & 2.2 & 76 & 2.8 \\
\hline Tigrai & 72 & 2.7 & 91 & 3.4 \\
\hline Gurage & 299 & II.I & 302 & 11.2 \\
\hline Other & 211 & 7.8 & 259 & 9.6 \\
\hline Education & $(\mathrm{N}=2698)$ & & $(\mathrm{N}=2698)$ & \\
\hline Illiterate & 340 & 12.6 & 78 & 2.9 \\
\hline Primary & 1083 & 40.1 & 917 & 34.0 \\
\hline $\begin{array}{l}\text { Secondary and } \\
\text { above }\end{array}$ & 1176 & 43.6 & 1529 & 56.6 \\
\hline Other & 99 & 3.7 & 176 & 6.5 \\
\hline Occupation & $(\mathrm{N}=2700)$ & & $(N=2700)$ & \\
\hline House wife & 1490 & 55.2 & - & - \\
\hline $\begin{array}{l}\text { Gov't } \\
\text { employee }\end{array}$ & 493 & 18.3 & 942 & 34.9 \\
\hline $\begin{array}{l}\text { Merchant/priv. } \\
\text { employee }\end{array}$ & 476 & 17.6 & 974 & 36.1 \\
\hline Daily laborer & - & - & 445 & 16.5 \\
\hline Other & $24 I$ & 8.9 & 339 & 12.6 \\
\hline
\end{tabular}




\section{The Use of Modern Contraceptive Methods by Couples}

About 2325 (86.1\%) women ever used modern contraceptive methods in the study area. About 1538 (57.1\% 95\% CI: $0.53,3.39$ ) women were current contraceptive users. From those who were not current contraceptive users, $38.6 \%$ intended to use contraceptives in the future while the majority $(56.1 \%)$ intended not to use in the future. The remaining $5.3 \%$ were undecided. Women who were currently using modern contraceptives were further asked to tell the type of contraceptives they used, 38.2\% used implants, 37.4\% used injectables, $0.9 \%$ used female sterilization and the remaining $23.5 \%$ used other methods. The level of covert contraceptive use among the study participants was $8.2 \%$. Those women who ever used modern contraceptives were further asked about the type of modern contraceptive methods they ever used. Accordingly, the most commonly used contraceptive methods were injectables $(46 \%)$ and pills $(25 \%)$ together constituting $71 \%$ while female sterilization constitutes only one percent and other methods constitute 29\% (Figure 1).

From a total of 2286 women who were asked about the purpose of their use of modern contraceptives, $87.3 \%$ reported for spacing birth, $4.4 \%$ for limiting birth and $8.3 \%$ for other purposes (such as to delay first birth, because of recommendations by physicians due to health problems, etc). The study participants were asked the question whether

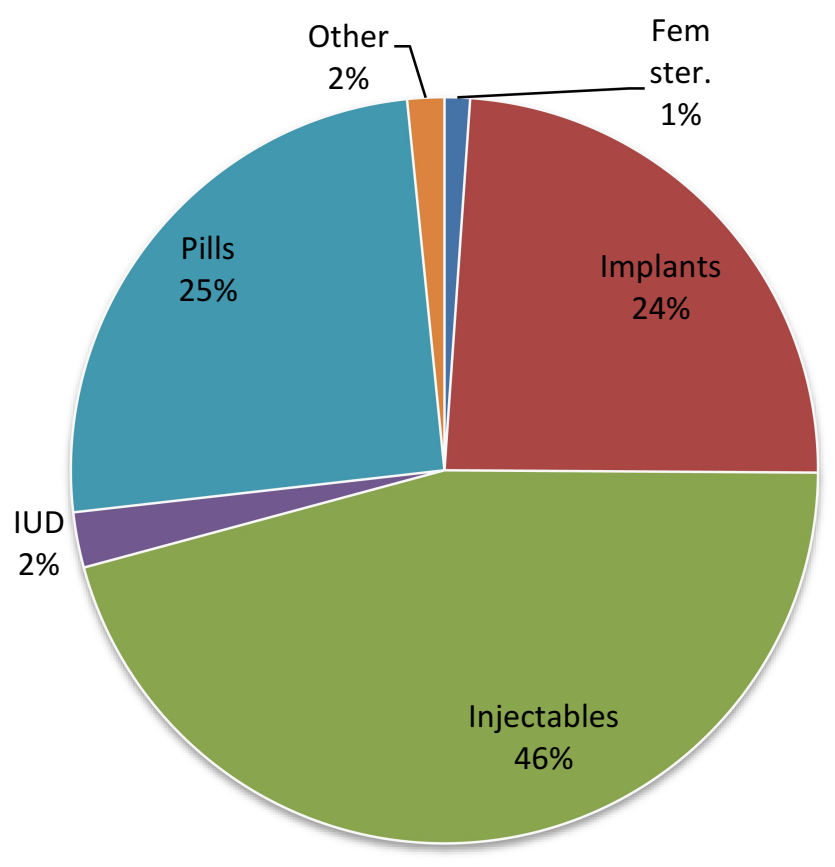

Figure I Distribution of women based on the type of contraceptive methods ever used, Harar, Eastern Ethiopia, 2019. contraceptives have side effects or not ${ }^{30}$ and from a total of 2681 women who responded to this question, 59.6\% reported that contraceptives have side effects. These respondents were further asked to name these side effects. Thus, $21.3 \%$ reported that use of contraceptives causes headaches followed by it takes too much time to get pregnant after stopping using contraceptives (19.1\%) (Table 2).

Of 2684 men who responded to ever use of contraceptives, 697 (26\%) ever used contraceptives. These men were further asked to tell the type of contraceptives they used. Thus, 694 (99.6\%) used male condom and $3(0.4 \%)$ used male sterilization. Men were also asked about their current contraceptive use. Of 2646 men who responded to current contraceptive use, only $60(2.3 \%)$ were current contraceptive users. These men were further asked to mention the type of contraceptives they used. Hence, 57 (95.0\%) used male condom and $3(5.0 \%)$ used male sterilization.

From a total of 2688 women who responded to the question have you ever experienced opposition from your husband for trying to use family planning, 9.2\% reported they experienced opposition, $89.1 \%$ never and $1.8 \%$ reported other. Price of contraceptives has a potential to impact on the contraceptive use of couples. The respondents were asked how much the contraceptive methods cost in their areas using the question "The last time you obtained the current method, how much did it cost you?". Accordingly, from a total of 1525 women who responded to this question, $86.3 \%$ reported that they got their's free of charge, $8.3 \%$ reported that it costs less than

Table 2 Distribution of Couples by Side Effects of Using Family Planning, Harar, Eastern Ethiopia, 2019

\begin{tabular}{|l|l|l|l|l|}
\hline \multicolumn{3}{|c|}{ Women (N=1597) } & \multicolumn{2}{l|}{ Men (N=I 154) } \\
\hline Side Effects & Frequency & Percent & Frequency & Percent \\
\hline $\begin{array}{l}\text { Breakthrough } \\
\text { bleeding }\end{array}$ & 167 & 10.5 & 121 & 10.5 \\
\hline $\begin{array}{l}\text { Disruption of } \\
\text { menstrual } \\
\text { cycle }\end{array}$ & 150 & 9.4 & 60 & 5.2 \\
\hline Headaches & 340 & 21.3 & 171 & 14.8 \\
\hline $\begin{array}{l}\text { Taking time to } \\
\text { get pregnant }\end{array}$ & 305 & 19.1 & 372 & 32.2 \\
\hline Weight gain & 224 & 14.0 & 209 & 18.1 \\
\hline Weight loss & 171 & 10.7 & 87 & 7.5 \\
\hline Other & 240 & 15.0 & 134 & 11.6 \\
\hline
\end{tabular}


or equal to 10 Ethiopian Birr (or less than or equal to 0.29 US Dollar) and 4.9\% reported it costs 11 Ethiopian Birr and above (or 0.31 US Dollar and above). The remaining $0.5 \%$ reported that they did not know the issue.

\section{Spousal Family Planning Communication and Couples' Approval of Family Planning} The level of spousal family planning communication in the study area was found to be very high. About $2212(82 \%)$ women and $2275(84.6 \%)$ men reported that they communicated about family planning in the last 12 months prior to the survey date. The level of spousal family planning communication was $89.6 \%$ (2420 couples) as reported by one or both spouses. However, the level of effective spousal family planning communication was found to be very low, i.e., 1010 (38\%) couples had effective communication. Couples who reported communicating about family planning in the last year were further asked the contents they communicated. Of 2420 couples, $43.8 \%$ communicated about spacing of childbirth while $32.9 \%$ communicated about number of children they want to have in their lifetime (Figure 2).

The study participants were also asked about the frequency of their communication on family planning in the last 12 months prior to the survey date. Accordingly, of 2212 women, $18 \%$ communicated once or twice, $71.6 \%$ sometimes, $8.6 \%$ more often and $1.8 \%$ rarely. Similarly, of 2275 men, $18.3 \%$ communicated once or twice, $71.1 \%$ sometimes, $8.4 \%$ more often and $2.2 \%$ rarely. The combined response to frequency of spousal family planning communication indicates that about 1235 (60.1\%) couples communicated only sometimes in the past 12 months prior to the survey date and 68 (3.3\%) couples reported communicating frequently (Figure 3 ).

Of 2697 women, $82.6 \%$ perceived that their husbands approved the use of family planning. About $15.8 \%$ of women perceived that their husbands disapproved the use of family planning while $1.6 \%$ of women perceived that they did not know the stand of their husbands. Similarly, of 2694 men, $83.7 \%$ perceived that their wives approved the use of family planning. About $14 \%$ of men perceived that their wives disapproved the use of family planning while $2.3 \%$ of men did not know the stand of their wives. Of $2692 \mathrm{men}$, $80.7 \%$ approved the use of family planning and $18.3 \%$ disapproved the use of it while one percent were not sure. Likewise, of 2699 women, $87.2 \%$ approved the use of family planning, $12.1 \%$ disapproved the use of family planning while $0.7 \%$ were not sure.

From 2577 women, 55.6\% wanted the same number of children as their husbands, $15.2 \%$ wanted more, $18.2 \%$ wanted fewer and $11 \%$ did not know. In the same way, from 2689 men, $50.6 \%$ wanted the same number of children as their wives, $27 \%$ wanted more, $11.5 \%$ wanted fewer and $10.9 \%$ did not know. About 1830 (68.1\%) women and 1219 (45.6\%) men reported that they discussed about family planning with their friends/relatives/neighbors other than their partners in the last 12 months prior to the survey date.

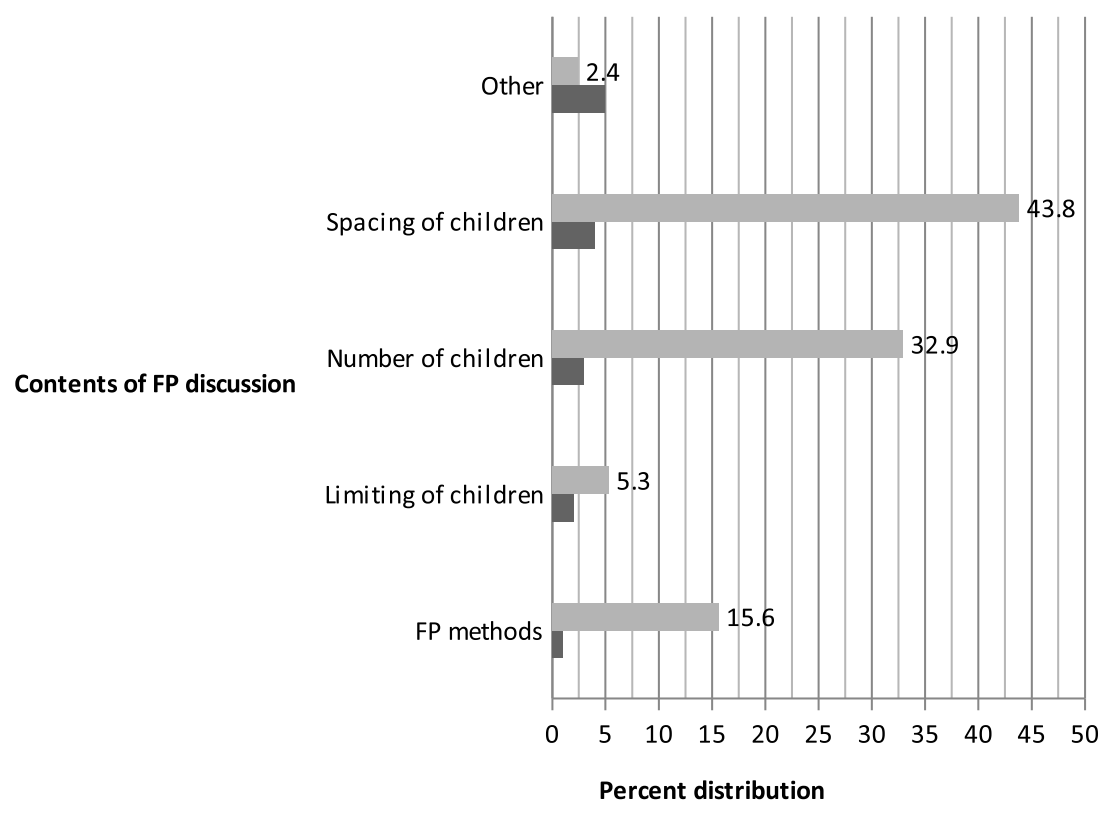

Figure 2 Distribution of couples based on the contents of FP communication, Harar, Eastern Ethiopia, 2019. 


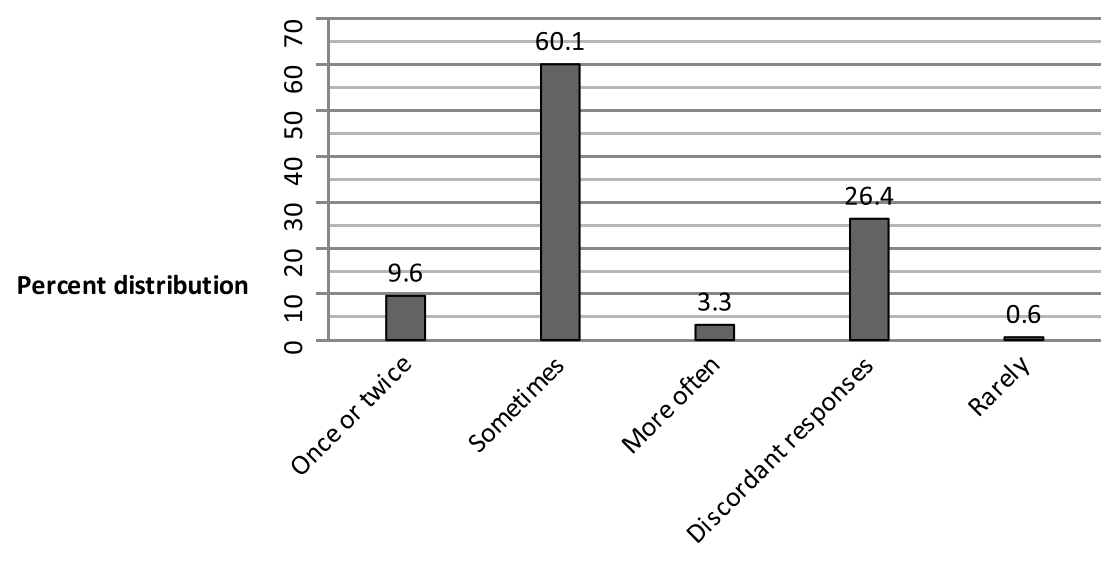

Frequency of communication

Figure 3 Distribution of couples based on the frequency of FP communication, Harar, Eastern Ethiopia, 2019.

\section{Bivariate Analysis}

Table 3 shows the association between current contraceptive use and the socio-economic and demographic characteristics of couples. The result showed that $60.6 \%$ couples aged less than 35 years were using contraceptives while $47.5 \%$ of couples from age group 35 years and above were using contraceptives $\left(\chi^{2}=48.99 ; \mathrm{P}=0.000\right)$. Age at first marriage of both men $\left(\chi^{2}=1.49 ; \mathrm{P}=0.474\right)$ and women $\left(\chi^{2}=0.23 ; \mathrm{P}=0.894\right)$ and age difference between couples $\left(\chi^{2}=1.95 ; \mathrm{P}=0.376\right)$ were not significantly associated with current modern contraceptive use. Duration of current marriage of couples was significantly associated with current modern contraceptive use $\left(\chi^{2}=15.49 ; \mathrm{P}=0.000\right)$. Of couples who were followers of Christianity $63.4 \%$ were current contraceptive users while only $48.1 \%$ Muslims were current contraceptive users. Similarly, of couples who had one to two living children $59.5 \%$ were currently using modern contraceptive methods while $61.6 \%$ couples with three to four living children were current contraceptive users (Table 3).

More than sixty percent of couples who desired one to four children and a little less than fifty percent of couples who desired five and above children were current modern contraceptive users. Of couples who desired to have no more children $57.1 \%$, from couples who desired to have another children $55.1 \%$, and from couples in which either husband or wife desired to have no more children in the future $61.7 \%$ were current contraceptive users $\left(\chi^{2}=15.01 ; \mathrm{P}=0.002\right)$. Of couples with house hold monthly income less than or equal to three thousand Ethiopian Birr, $61.2 \%$ were current contraceptive users while from couples with household monthly income of between three thousand and six thousand and above six thousand, $51.1 \%$ and $51.9 \%$ were current contraceptive users $\left(\chi^{2}=25.62 ; \mathrm{P}=0.000\right)$, respectively. From couples in the lowest wealth index, $55.4 \%$ were current contraceptive users while from the highest wealth index, $56.5 \%$ were current contraceptive users.

Of couples in which both approve family planning, $64.9 \%$ were current contraceptive users while from a category in which both disapprove family planning, only $5.9 \%$ were current contraceptive users $(\mathrm{P}<0.05)$. About $70 \%$ of women who were counseled about family planning by health workers were current contraceptive users while $51.2 \%$ of women who were not counseled about family planning were current contraceptive users. Similarly, $66.7 \%$ of men who were counseled about family planning by health workers were current contraceptive users while $54.8 \%$ of men who were not counseled about family planning were current contraceptive users. The proportion of men visited by health extension workers was only $23 \%$ (619 out of 2694) while this proportion was $52.3 \%$ (1408 out of 2691) for women in the last 12 months prior to the survey date (Table 4).

About $63.6 \%$ of couples who discussed family planning with friends/relatives and $46.6 \%$ who did not discuss were using modern contraceptive methods. Of couples who reported the final decision to use family planning methods is made by husband and jointly by husband and wife, $43.3 \%$ and $58.3 \%$ were current contraceptive users, respectively. Couple's exposure to family planning messages in the last six months on TV $\left(\chi^{2}=24.65\right.$; $\mathrm{P}=0.000)$, in newspaper $\left(\chi^{2}=6.32 ; \mathrm{P}=0.042\right)$, in pamphlets $\left(\chi^{2}=30.43 ; \mathrm{P}=0.000\right)$, and community events $\left(\chi^{2}=22.76 ; \mathrm{P}=0.000\right)$ were significantly associated 
Table 3 Current Contraceptive Use by Socio-Economic and Demographic Characteristics of Husbands, Wives and Couples, Harar, Eastern Ethiopia, 2019

\begin{tabular}{|c|c|c|c|c|}
\hline \multirow[t]{2}{*}{ Variables } & \multicolumn{2}{|c|}{$\begin{array}{l}\text { Current } \\
\text { Contraceptive } \\
\text { Use }\end{array}$} & \multirow[t]{2}{*}{$\begin{array}{l}\text { Chi- } \\
\text { Square }\end{array}$} & \multirow[t]{2}{*}{ P-value } \\
\hline & $\begin{array}{l}\text { Yes } \\
\text { (\%) }\end{array}$ & $\begin{array}{l}\text { No } \\
\text { (\%) }\end{array}$ & & \\
\hline
\end{tabular}

\section{Age of couples}

\begin{tabular}{|l|l|l|l|l|}
\hline Both <35 years & $\begin{array}{l}531 \\
(60.6)\end{array}$ & $\begin{array}{l}345 \\
(39.4)\end{array}$ & 48.99 & 0.000 \\
\hline Both 35+ years & $\begin{array}{l}412 \\
(47.5)\end{array}$ & $\begin{array}{l}456 \\
(52.5)\end{array}$ & & \\
\hline $\begin{array}{l}\text { Husband 35+ years and } \\
\text { wife }<35 \text { years }\end{array}$ & $\begin{array}{l}594 \\
(62.6)\end{array}$ & $\begin{array}{l}355 \\
(37.4)\end{array}$ & & \\
\hline
\end{tabular}

\section{Religion of couples}

\begin{tabular}{|l|l|l|l|l|}
\hline Both Muslim & $\begin{array}{l}517 \\
(48.1)\end{array}$ & $\begin{array}{l}557 \\
(51.9)\end{array}$ & 59.60 & 0.000 \\
\hline Both Christian & $\begin{array}{l}919 \\
(63.4)\end{array}$ & $\begin{array}{l}530 \\
(36.6)\end{array}$ & & \\
\hline Other & $\begin{array}{l}92 \\
(60.5)\end{array}$ & $\begin{array}{l}60 \\
(39.5)\end{array}$ & & \\
\hline
\end{tabular}

\section{Education of couples}

\begin{tabular}{|l|l|l|l|l|}
\hline Both illiterate & $\begin{array}{l}25 \\
(69.4)\end{array}$ & $\begin{array}{l}\text { II } \\
(30.6)\end{array}$ & 6.72 & 0.152 \\
\hline Both primary (I-8) & $\begin{array}{l}27 \mathrm{I} \\
(56.7)\end{array}$ & $\begin{array}{l}207 \\
(43.3)\end{array}$ & & \\
\hline Both secondary+ & $\begin{array}{l}478 \\
(54.8)\end{array}$ & $\begin{array}{l}394 \\
(45.2)\end{array}$ & & \\
\hline Either of them educated & $\begin{array}{l}749 \\
(58.6)\end{array}$ & $\begin{array}{l}528 \\
(4 I .4)\end{array}$ & & \\
\hline Both other & $\begin{array}{l}14 \\
(46.7)\end{array}$ & $\begin{array}{l}16 \\
(53.3)\end{array}$ & & \\
\hline
\end{tabular}

\section{Occupation of women}

\begin{tabular}{|l|l|l|l|l|}
\hline Merchant/priv. emp & $\begin{array}{l}270 \\
(56.8)\end{array}$ & $\begin{array}{l}205 \\
(43.2)\end{array}$ & 4.64 & 0.200 \\
\hline Gov't emp & $\begin{array}{l}261 \\
(52.9)\end{array}$ & $\begin{array}{l}232 \\
(47.1)\end{array}$ & & \\
\hline Housewife & $\begin{array}{l}864 \\
(58.1)\end{array}$ & $\begin{array}{l}622 \\
(41.9)\end{array}$ & & \\
\hline Other & $\begin{array}{l}143 \\
(59.3)\end{array}$ & $\begin{array}{l}98 \\
(40.7)\end{array}$ & & \\
\hline
\end{tabular}

(Continued)
Table 3 (Continued).

\begin{tabular}{|l|l|l|l|l|}
\hline Variables & \multicolumn{2}{|l|}{$\begin{array}{l}\text { Current } \\
\text { Contraceptive } \\
\text { Use }\end{array}$} & $\begin{array}{l}\text { Chi- } \\
\text { Square }\end{array}$ & P-value \\
\cline { 2 - 3 } & $\begin{array}{l}\text { Yes } \\
\text { (\%) }\end{array}$ & $\begin{array}{l}\text { No } \\
\text { (\%) }\end{array}$ & & \\
\hline Occupation of men & \multicolumn{5}{|l}{} & \\
\hline Merchant/priv. emp & $\begin{array}{l}589 \\
(60.6)\end{array}$ & $\begin{array}{l}383 \\
(39.4)\end{array}$ & 9.98 & 0.019 \\
\hline Gov't emp & $\begin{array}{l}517 \\
(54.9)\end{array}$ & $\begin{array}{l}424 \\
(45.1)\end{array}$ & & \\
\hline Daily laborer & $\begin{array}{l}255 \\
(57.6)\end{array}$ & $\begin{array}{l}188 \\
(42.4)\end{array}$ & & \\
\hline Other & $\begin{array}{l}177 \\
(52.2)\end{array}$ & $\begin{array}{l}162 \\
(47.8)\end{array}$ & & \\
\hline
\end{tabular}

Number of living children

\begin{tabular}{|l|l|l|l|l|}
\hline I-2 children & $\begin{array}{l}846 \\
(59.5)\end{array}$ & $\begin{array}{l}575 \\
(40.5)\end{array}$ & II.40 & 0.003 \\
\hline $3-4$ children & $\begin{array}{l}449 \\
(61.6)\end{array}$ & $\begin{array}{l}280 \\
(38.4)\end{array}$ & & \\
\hline $5+$ children & $\begin{array}{l}16 \mathrm{I} \\
(50.6)\end{array}$ & $\begin{array}{l}157 \\
(49.4)\end{array}$ & & \\
\hline
\end{tabular}

Desired number of children

\begin{tabular}{|l|l|l|l|l|}
\hline Both want I-4 children & $\begin{array}{l}653 \\
(63.8)\end{array}$ & $\begin{array}{l}370 \\
(36.2)\end{array}$ & 48.86 & 0.000 \\
\hline Both want 5+ children & $\begin{array}{l}302 \\
(46.8)\end{array}$ & $\begin{array}{l}344 \\
(53.2)\end{array}$ & & \\
\hline Discordant desires & $\begin{array}{l}549 \\
(57.2)\end{array}$ & $\begin{array}{l}410 \\
(42.8)\end{array}$ & & \\
\hline Other & $\begin{array}{l}24 \\
(48.0)\end{array}$ & $\begin{array}{l}26 \\
(52.0)\end{array}$ & & \\
& & & \\
\hline
\end{tabular}

Number of children husband wants compared to his wife

\begin{tabular}{|l|l|l|l|l|}
\hline Same & $\begin{array}{l}775 \\
(87.1)\end{array}$ & $\begin{array}{l}583 \\
(42.9)\end{array}$ & 9.86 & 0.020 \\
\hline More & $\begin{array}{l}400 \\
(55.2)\end{array}$ & $\begin{array}{l}325 \\
(44.8)\end{array}$ & & \\
\hline Fewer & $\begin{array}{l}201 \\
(64.8)\end{array}$ & $\begin{array}{l}109 \\
(35.2)\end{array}$ & & \\
\hline Do not know & $\begin{array}{l}157 \\
(54.0)\end{array}$ & $\begin{array}{l}134 \\
(46.0)\end{array}$ & & \\
\hline
\end{tabular}


Table 3 (Continued).

\begin{tabular}{|c|c|c|c|c|}
\hline \multirow[t]{2}{*}{ Variables } & \multicolumn{2}{|c|}{$\begin{array}{l}\text { Current } \\
\text { Contraceptive } \\
\text { Use }\end{array}$} & \multirow[t]{2}{*}{$\begin{array}{l}\text { Chi- } \\
\text { Square }\end{array}$} & \multirow[t]{2}{*}{ P-value } \\
\hline & $\begin{array}{l}\text { Yes } \\
\text { (\%) }\end{array}$ & $\begin{array}{l}\text { No } \\
\text { (\%) }\end{array}$ & & \\
\hline \multicolumn{5}{|c|}{ Number of children woman wants compared to her husband } \\
\hline Same & $\begin{array}{l}829 \\
(58.0)\end{array}$ & $\begin{array}{l}599 \\
(42.0)\end{array}$ & 5.24 & 0.155 \\
\hline More & $\begin{array}{l}227 \\
(58.2)\end{array}$ & $\begin{array}{l}163 \\
(41.8)\end{array}$ & & \\
\hline Fewer & $\begin{array}{l}269 \\
(57.4)\end{array}$ & $\begin{array}{l}200 \\
(42.6)\end{array}$ & & \\
\hline Do not know & $\begin{array}{l}145 \\
(50.9)\end{array}$ & $\begin{array}{l}140 \\
(49.1)\end{array}$ & & \\
\hline \multicolumn{5}{|l|}{ Wealth index } \\
\hline Lowest & $\begin{array}{l}283 \\
(55.4)\end{array}$ & $\begin{array}{l}228 \\
(44.6)\end{array}$ & 10.96 & 0.027 \\
\hline Second & $\begin{array}{l}313 \\
(58.1)\end{array}$ & $\begin{array}{l}226 \\
(41.9)\end{array}$ & & \\
\hline Middle & $\begin{array}{l}308 \\
(63.0)\end{array}$ & $\begin{array}{l}181 \\
(37.0)\end{array}$ & & \\
\hline Fourth & $\begin{array}{l}273 \\
(53.2)\end{array}$ & $\begin{array}{l}240 \\
(46.8)\end{array}$ & & \\
\hline Highest & $\begin{array}{l}290 \\
(56.5)\end{array}$ & $\begin{array}{l}223 \\
(43.5)\end{array}$ & & \\
\hline
\end{tabular}

with current modern contraceptive use. On the other hand, couples exposure to family planning message in the last six months on radio $\left(\chi^{2}=0.37 ; \mathrm{P}=0.831\right)$ was not significantly associated with current modern contraceptive use. Of those couples who agree to the large family size ideal, $49.4 \%$ were current contraceptive users while from those who disagree, $68.7 \%$ were current contraceptive users. Of those couples where either husband or wife agree to the large family size ideal, $58.3 \%$ were current contraceptive users $\left(\chi^{2}=56.93 ; \mathrm{P}=0.000\right)$ (Table 4).

About $59.2 \%$ of couples who had communication about family planning in the last 12 months prior to the survey date were contraceptive users while only $39.2 \%$ of noncommunicators were current contraceptive users. Similarly, $64 \%$ of couples who had effective communication were current contraceptive users while $53 \%$ of couples who had noneffective communication were current contraceptive users.
Table 4 Current Contraceptive Use by Knowledge and Attitude Towards Family Planning of Couples, Harar, Eastern Ethiopia, 2019

\begin{tabular}{|c|c|c|c|c|}
\hline \multirow[t]{2}{*}{ Variables } & \multicolumn{2}{|c|}{$\begin{array}{l}\text { Current } \\
\text { Contraceptive } \\
\text { Use }\end{array}$} & \multirow[t]{2}{*}{$\begin{array}{l}\text { Chi- } \\
\text { Square }\end{array}$} & \multirow[t]{2}{*}{ P-value } \\
\hline & $\begin{array}{l}\text { Yes } \\
\text { (\%) }\end{array}$ & $\begin{array}{l}\text { No } \\
\text { (\%) }\end{array}$ & & \\
\hline
\end{tabular}

\section{Number of FP methods couples know}

\begin{tabular}{|l|l|l|l|l|}
\hline Both know <5 methods & $\begin{array}{l}147 \\
(52.9)\end{array}$ & $\begin{array}{l}131 \\
(47.1)\end{array}$ & 5.17 & 0.160 \\
\hline Both know 5+ methods & $\begin{array}{l}106 \mathrm{I} \\
(58.6)\end{array}$ & $\begin{array}{l}75 \mathrm{I} \\
(4 \mathrm{I} .4)\end{array}$ & & \\
\hline $\begin{array}{l}\text { Husband<5 and wife 5+ } \\
\text { methods }\end{array}$ & $\begin{array}{l}182 \\
(55.1)\end{array}$ & $\begin{array}{l}148 \\
(44.9)\end{array}$ & & \\
\hline $\begin{array}{l}\text { Husband 5+ and wife <5 } \\
\text { methods }\end{array}$ & $\begin{array}{l}123 \\
(53.7)\end{array}$ & $\begin{array}{l}106 \\
(46.3)\end{array}$ & & \\
\hline
\end{tabular}

Couples' approval of family planning

\begin{tabular}{|l|l|l|l|l|}
\hline Both approve & $\begin{array}{l}1299 \\
(64.9)\end{array}$ & $\begin{array}{l}702 \\
(35.1)\end{array}$ & 268.0 & 0.000 \\
\hline Both disapprove & $10(5.9)$ & $\begin{array}{l}159 \\
(94.1)\end{array}$ & & \\
\hline Either approve & $\begin{array}{l}226 \\
(43.8)\end{array}$ & $\begin{array}{l}290 \\
(56.2)\end{array}$ & & \\
\hline
\end{tabular}

Family planning counseling by health workers of women

\begin{tabular}{|l|l|l|l|l|}
\hline Yes & $\begin{array}{l}613 \\
(70.0)\end{array}$ & $\begin{array}{l}263 \\
(30.0)\end{array}$ & 71.50 & 0.000 \\
\hline No & $\begin{array}{l}563 \\
(51.2)\end{array}$ & $\begin{array}{l}537 \\
(48.8)\end{array}$ & & \\
\hline
\end{tabular}

Family planning counseling by health workers of men

\begin{tabular}{|l|l|l|l|l|}
\hline Yes & $\begin{array}{l}196 \\
(66.7)\end{array}$ & $\begin{array}{l}98 \\
(33.3)\end{array}$ & 12.35 & 0.000 \\
\hline No & $\begin{array}{l}428 \\
(54.8)\end{array}$ & $\begin{array}{l}353 \\
(45.2)\end{array}$ & & \\
\hline
\end{tabular}

Couples family planning communication

\begin{tabular}{|l|l|l|l|l|}
\hline Yes & $\begin{array}{l}1429 \\
(59.2)\end{array}$ & $\begin{array}{l}986 \\
(40.8)\end{array}$ & 38.73 & 0.000 \\
\hline No & $\begin{array}{l}104 \\
(39.2)\end{array}$ & $\begin{array}{l}161 \\
(60.8)\end{array}$ & & \\
\hline \multicolumn{7}{|l|}{ Type of couples family planning communication } \\
\hline Effective communication & $\begin{array}{l}644 \\
(64.0)\end{array}$ & $\begin{array}{l}363 \\
(36.0)\end{array}$ & 30.40 & 0.000 \\
\hline
\end{tabular}

(Continued) 
Table 4 (Continued).

\begin{tabular}{|c|c|c|c|c|}
\hline \multirow[t]{2}{*}{ Variables } & \multicolumn{2}{|c|}{$\begin{array}{l}\text { Current } \\
\text { Contraceptive } \\
\text { Use }\end{array}$} & \multirow[t]{2}{*}{$\begin{array}{l}\text { Chi- } \\
\text { Square }\end{array}$} & \multirow[t]{2}{*}{ P-value } \\
\hline & $\begin{array}{l}\text { Yes } \\
\text { (\%) }\end{array}$ & $\begin{array}{l}\text { No } \\
\text { (\%) }\end{array}$ & & \\
\hline $\begin{array}{l}\text { Non-effective } \\
\text { communication }\end{array}$ & $\begin{array}{l}873 \\
(53.0)\end{array}$ & $\begin{array}{l}773 \\
(47.0)\end{array}$ & & \\
\hline
\end{tabular}

Frequency of spousal family planning communication

\begin{tabular}{|l|l|l|l|l|}
\hline More often & $\begin{array}{l}4 I \\
(6 I .2)\end{array}$ & $\begin{array}{l}26 \\
(38.8)\end{array}$ & 25.25 & 0.000 \\
\hline Once/twice & $\begin{array}{l}96 \\
(45.7)\end{array}$ & $\begin{array}{l}114 \\
(54.3)\end{array}$ & & \\
\hline Sometimes & $\begin{array}{l}789 \\
(63.9)\end{array}$ & $\begin{array}{l}445 \\
(36.1)\end{array}$ & & \\
\hline Discordant responses & $\begin{array}{l}325 \\
(60.2)\end{array}$ & $\begin{array}{l}215 \\
(39.8)\end{array}$ & & \\
\hline
\end{tabular}

Couples FP discussion with friends/relatives/neighbors

\begin{tabular}{|l|l|l|l|l|}
\hline Both discussed & $\begin{array}{l}626 \\
(63.6)\end{array}$ & $\begin{array}{l}358 \\
(36.4)\end{array}$ & 44.84 & 0.000 \\
\hline Both not discussed & $\begin{array}{l}287 \\
(46.6)\end{array}$ & $\begin{array}{l}329 \\
(53.4)\end{array}$ & & \\
\hline Either of them discussed & $\begin{array}{l}604 \\
(57.1)\end{array}$ & $\begin{array}{l}453 \\
(42.9)\end{array}$ & & \\
\hline
\end{tabular}

Final decision to use family planning methods

\begin{tabular}{|l|l|l|l|l|}
\hline Husband & $\begin{array}{l}74 \\
(43.3)\end{array}$ & $\begin{array}{l}97 \\
(56.7)\end{array}$ & 18.97 & 0.000 \\
\hline Wife & $\begin{array}{l}515 \\
(57.9)\end{array}$ & $\begin{array}{l}374 \\
(42.1)\end{array}$ & & \\
\hline Joint (husband and wife) & $\begin{array}{l}944 \\
(58.3)\end{array}$ & $\begin{array}{l}676 \\
(41.7)\end{array}$ & & \\
\hline Other & $2(22.2)$ & $\begin{array}{l}7 \\
(77.8)\end{array}$ & & \\
\hline
\end{tabular}

About $61.2 \%$ of frequent communicators, $45.7 \%$ of couples who communicated once or twice, $63.9 \%$ who communicated sometimes and $60.2 \%$ of couples who reported discordant responses were current modern contraceptive users (Table 4).

We fitted three models. The first model assesses the association between effective spousal family planning communication, socio-economic and demographic variables and current modern contraceptive use. The second model assesses the association between family planning communication, attitude and exposure to family planning messages and current modern contraceptive use. The third model assesses the association between socio-economic, demographic and family planning communication, attitude and exposure to the family planning message and current modern contraceptive use by taking variables significant at P-value less than 0.1 from the two models (Table 5).

\section{Multivariable Analysis}

In the final model of multivariable analysis: effective spousal family planning communication $(\mathrm{OR}=1.1 ; 95 \% \mathrm{CI}$ : $1.02,1.21)$, age of couples, religion of couples $(\mathrm{OR}=1.2$; $95 \%$ CI: $1.10,1.35)$, number of living children $(\mathrm{OR}=1.2$; 95\% CI: 1.10, 1.31), household monthly income, couples approval of FP use (OR $=4.7 ; 95 \%$ CI: 2.19, 10.01), women's FP counseling by health workers $(\mathrm{OR}=1.2$; 95\% CI: 1.09, 1.29), frequency of couples' FP communication and couples' exposure to FP message in newspapers were found significantly associated with modern contraceptive use of women (Table 5).

\section{Discussion}

This study demonstrated that little higher than one-third of couples had effective communication about family planning. Younger age and affiliation of couples to Christianity, number of children couples had, household monthly income, couples FP approval, women's counseling about FP by HW, couples' frequency of FP communication and couples' exposure to FP message in newspapers were significantly associated with current modern contraceptive use.

Research suggests that spousal family planning communication positively influences contraceptive use and increases shared decision-making. ${ }^{10}$ The significant association found between spousal family planning communication and current modern contraceptive use among women in the current study is comparable with findings in Akwa Ibom state of Nigeria and a study in Bangladesh in which couples who had favorable spousal communication were more likely to be contraceptive users compared to couples who had unfavorable communication. ${ }^{2,31}$ Similarly, in a study conducted in Hossana town, Southern Ethiopia, couples who had communication about family planning were found to be more likely to use contraceptives compared to their counterparts. ${ }^{11}$ However, the current finding is different from the finding in a study in Nigeria in which spousal family planning communication is not associated with couples' contraceptive use. ${ }^{32}$ 
Table 5 Poisson Regression Coefficients of Contraceptive Use by Selected Socio-Economic and Demographic and Family Planning Communication and Attitude Variables, Harar, Eastern Ethiopia, 2019

\begin{tabular}{|c|c|c|c|}
\hline \multirow[t]{2}{*}{ Variables } & Model I & Model 2 & Model 3 \\
\hline & aPR $(95 \% \mathrm{Cl})$ & $\operatorname{aPR}(95 \% \mathrm{Cl})$ & $\operatorname{aPR}(95 \% \mathrm{Cl})$ \\
\hline \multicolumn{4}{|l|}{ Spousal FP communication } \\
\hline Effective communication & $1.19(1.10,1.28)^{*}$ & & I.II $(1.02, I .21)^{*}$ \\
\hline \multicolumn{4}{|l|}{ Non-effective communication(RC) } \\
\hline \multicolumn{4}{|l|}{ Age of couples } \\
\hline \multicolumn{4}{|l|}{ Both <35 years $(\mathrm{RC})$} \\
\hline Both $35+$ years & $0.68(0.61,0.77)^{*}$ & & $0.84(0.73,0.96)^{*}$ \\
\hline Husband $35+$ and wife $<35$ yrs & $0.96(0.88,1.04)$ & & $0.99(0.90,1.08)$ \\
\hline \multicolumn{4}{|l|}{ Duration of current marriage } \\
\hline \multicolumn{4}{|l|}{$<5$ years $(\mathrm{RC})$} \\
\hline $5-10$ years & $1.12(1.01,1.24)^{*}$ & & $1.05(0.94,1.17)$ \\
\hline $11+$ years & I.00 (0.89,I.I3) & & $0.94(0.83,1.08)$ \\
\hline \multicolumn{4}{|l|}{ Religion of couples } \\
\hline \multicolumn{4}{|l|}{ Both Muslim (RC) } \\
\hline Both Christian & $1.4 \mathrm{I}(1.28, \mathrm{I} .55)^{*}$ & & $1.22(1.09,1.35)^{*}$ \\
\hline Other & $1.16(1.00,1.36)$ & & I.I8 $(0.99, I .4 I)$ \\
\hline \multicolumn{4}{|l|}{ Education of couples } \\
\hline \multicolumn{4}{|l|}{ Both illiterate (RC) } \\
\hline Both primary (I-8 grade) & $0.84(0.65,1.09)$ & & \\
\hline Secondary and above & $0.77(0.59, \mathrm{I} .0 \mathrm{I})$ & & \\
\hline Either of them educated & $0.85(0.66,1.09)$ & & \\
\hline Other & $0.77(0.49, I .2 I)$ & & \\
\hline \multicolumn{4}{|l|}{ Occupation of women } \\
\hline \multicolumn{4}{|l|}{ House wife (RC) } \\
\hline Merchant/priv. employee & I.0I $(0.92, I .12)$ & & \\
\hline Government employee & $0.97(0.87,1.07)$ & & \\
\hline Other & I.0I $(0.89,1.15)$ & & \\
\hline \multicolumn{4}{|l|}{ Occupation of men } \\
\hline \multicolumn{4}{|l|}{ Merchant/priv. employee (RC) } \\
\hline Government employee & $0.99(0.91,1.08)$ & & \\
\hline Daily laborer & $0.98(0.88,1.08)$ & & \\
\hline Other & $0.88(0.78,1.00)$ & & \\
\hline
\end{tabular}


Table 5 (Continued).

\begin{tabular}{|c|c|c|c|}
\hline \multirow[t]{2}{*}{ Variables } & Model I & Model 2 & Model 3 \\
\hline & aPR (95\% Cl) & aPR $(95 \% \mathrm{Cl})$ & aPR $(95 \% \mathrm{Cl})$ \\
\hline \multicolumn{4}{|c|}{ Number of living children } \\
\hline \multicolumn{4}{|l|}{ I-2 children (RC) } \\
\hline 3-4 children & $1.20(1.10,1.30)^{*}$ & & $1.20(1.10,1.31)^{*}$ \\
\hline $5+$ children & $1.09(0.95,1.26)$ & & $1.09(0.93,1.27)$ \\
\hline \multicolumn{4}{|c|}{ Couples' desired number of children } \\
\hline \multicolumn{4}{|c|}{ Both want I-4 children (RC) } \\
\hline Both want $5+$ children & $0.88(0.78,0.99)^{*}$ & & $0.94(0.82,1.08)$ \\
\hline Discordant desires & $0.98(0.90,1.06)$ & & $0.99(0.91,1.09)$ \\
\hline Other & $0.62(0.39,0.98)^{* *}$ & & $0.60(0.35,1.03)$ \\
\hline \multicolumn{4}{|l|}{ Future fertility desire } \\
\hline \multicolumn{4}{|c|}{ Both want to have another child (RC) } \\
\hline Both want no more/none & $1.10(0.97,1.26)$ & & \\
\hline Discordant desires & $1.06(0.96,1.16)$ & & \\
\hline Other & $\mathrm{I} .25(\mathrm{I} .03, \mathrm{I} .5 \mathrm{I})$ & & \\
\hline \multicolumn{4}{|c|}{ Number of children wife wants compared to her husband } \\
\hline \multicolumn{4}{|l|}{ Do not know (RC) } \\
\hline Fewer & $1.07(0.93,1.23)$ & & \\
\hline More & $1.04(0.90,1.20)$ & & \\
\hline Same & I.II $(0.98,1.26)$ & & \\
\hline \multicolumn{4}{|c|}{ Number of children husband wants compared to his wife } \\
\hline \multicolumn{4}{|l|}{ Do not know (RC) } \\
\hline Fewer & $1.10(0.95,1.27)$ & & \\
\hline More & $1.01(0.89,1.14)$ & & \\
\hline Same & $0.98(0.86, \mathrm{I} . \mathrm{II})$ & & \\
\hline \multicolumn{4}{|c|}{ Household monthly income } \\
\hline \multicolumn{4}{|l|}{$\leq 3000$ birr $(\mathrm{RC})$} \\
\hline $300 \mathrm{I}-6000 \mathrm{birr}$ & $0.87(0.80,0.95)^{*}$ & & $0.85(0.77,0.93)^{*}$ \\
\hline $6001+$ birr & $0.95(0.85,1.07)$ & & $0.89(0.78,1.01)$ \\
\hline \multicolumn{4}{|l|}{ Wealth index } \\
\hline \multicolumn{4}{|l|}{ Poorest (RC) } \\
\hline Poorer & $0.99(0.88,1.10)$ & & \\
\hline Middle & $1.06(0.95,1.18)$ & & \\
\hline
\end{tabular}


Table 5 (Continued).

\begin{tabular}{|c|c|c|c|}
\hline \multirow[t]{2}{*}{ Variables } & Model I & Model 2 & Model 3 \\
\hline & $\operatorname{aPR}(95 \% \mathrm{Cl})$ & $\operatorname{aPR}(95 \% \mathrm{Cl})$ & aPR $(95 \% \mathrm{Cl})$ \\
\hline Richer & $0.93(0.82,1.05)$ & & \\
\hline Richest & $0.96(0.85,1.09)$ & & \\
\hline \multicolumn{4}{|l|}{ Number of family planning methods couples know } \\
\hline \multicolumn{4}{|l|}{ Both know <5 methods (RC) } \\
\hline Both know $5+$ methods & & $0.80(0.66,0.96)$ & \\
\hline Husband knows $<5$ methods and wife $5+$ methods & & $0.93(0.74, I .16)$ & \\
\hline Husband knows $5+$ methods and wife knows $<5$ methods & & $0.90(0.70,1.17)$ & \\
\hline \multicolumn{4}{|l|}{ Couples' approval of FP use } \\
\hline \multicolumn{4}{|l|}{ Both disapprove (RC) } \\
\hline Both approve & & $10.22(2.59,40.29)^{*}$ & $4.68(2.19,10.01)^{*}$ \\
\hline Either of them approve & & $6.69(1.68,26.73)^{*}$ & $3.05(1.40,6.64)^{*}$ \\
\hline \multicolumn{4}{|l|}{ Women's FP counseling by health workers } \\
\hline Counseled & & $1.22(1.08,1.38)^{*}$ & $1.19(1.09,1.29)^{*}$ \\
\hline \multicolumn{4}{|l|}{ Not counseled (RC) } \\
\hline \multicolumn{4}{|l|}{ Men's FP counseling by health workers } \\
\hline Counseled & & $0.98(0.86, \mathrm{I} . \mathrm{II})$ & \\
\hline \multicolumn{4}{|l|}{ Not counseled (RC) } \\
\hline \multicolumn{4}{|l|}{ Frequency of couples' FP communication } \\
\hline \multicolumn{4}{|l|}{ Once or twice (RC) } \\
\hline More often & & $1.38(0.96,1.99)^{* *}$ & $1.21(0.93,1.58)$ \\
\hline Sometimes & & $1.20(0.96,1.51)^{* *}$ & $1.22(1.03,1.44)^{*}$ \\
\hline Discordant responses & & $1.19(0.93,1.50)^{* *}$ & $1.22(1.02,1.45)^{*}$ \\
\hline \multicolumn{4}{|l|}{ Couples' FP communication with friends/neighbors } \\
\hline \multicolumn{4}{|l|}{ Both reported no communication (RC) } \\
\hline Both reported communication & & $1.02(0.83,1.24)$ & \\
\hline Either reported communication & & I.0I $(0.83,1.23)$ & \\
\hline \multicolumn{4}{|l|}{ Final decision to use family planning methods } \\
\hline \multicolumn{4}{|l|}{ Husband's (RC) } \\
\hline Wife's & & $1.57(1.06,2.33)^{*}$ & $1.05(0.85, I .28)$ \\
\hline Joint & & $1.57(1.06,2.31)^{*}$ & $1.03(0.84,1.25)$ \\
\hline Other & & $1.02(0.19,5.40)$ & $0.80(0.14,4.59)$ \\
\hline
\end{tabular}


Table 5 (Continued).

\begin{tabular}{|c|c|c|c|}
\hline \multirow[t]{2}{*}{ Variables } & Model I & Model 2 & Model 3 \\
\hline & aPR $(95 \% \mathrm{Cl})$ & aPR $(95 \% \mathrm{Cl})$ & aPR $(95 \% \mathrm{Cl})$ \\
\hline \multicolumn{4}{|c|}{ Exposure to FP message on TV } \\
\hline \multicolumn{4}{|l|}{ Both unexposed (RC) } \\
\hline Both exposed & & $1.73(0.95,3.15)^{* *}$ & $1.24(0.91,1.68)$ \\
\hline Either exposed & & $1.78(0.95,3.24)^{* *}$ & I.16 $(0.84,1.59)$ \\
\hline \multicolumn{4}{|c|}{ Exposure to FP message in Newspaper } \\
\hline \multicolumn{4}{|l|}{ Both unexposed (RC) } \\
\hline Both exposed & & $0.63(0.47,0.86)^{*}$ & $0.81(0.67,0.99)^{*}$ \\
\hline Either exposed & & $1.01(0.90,1.14)$ & $1.02(0.92,1.1 \mathrm{I})$ \\
\hline \multicolumn{4}{|c|}{ Exposure to FP message in Pamphlets } \\
\hline \multicolumn{4}{|l|}{ Both unexposed (RC) } \\
\hline Both exposed & & $1.12(0.94,1.34)$ & \\
\hline Either exposed & & $0.98(0.83,1.15)$ & \\
\hline \multicolumn{4}{|c|}{ Exposure to FP message at community events } \\
\hline \multicolumn{4}{|l|}{ Both unexposed (RC) } \\
\hline Both exposed & & $0.86(0.73,1.01)^{* *}$ & $1.00(0.89,1.13)$ \\
\hline Either exposed & & $0.8 \mathrm{I}(0.7 \mathrm{I}, 0.93)^{*}$ & $0.96(0.88,1.06)$ \\
\hline \multicolumn{4}{|c|}{ Couples' attitude towards large family size } \\
\hline \multicolumn{4}{|l|}{ Both agree $(\mathrm{RC})$} \\
\hline Both disagree & & $1.21(1.05,1.39)^{*}$ & $1.05(0.94,1.17)$ \\
\hline Either of them agree & & $1.16(1.02,1.32)^{*}$ & $1.01(0.92,1.12)$ \\
\hline
\end{tabular}

Notes: *Significant at $\mathrm{P}<0.05$; **Significant at $\mathrm{P}<0.1$.

Abbreviations: RC, reference category; aPR, adjusted prevalence ratio.

The prevalence ratio of current modern contraceptive use was higher among couples who had frequent communication ( $\mathrm{aPR}=1.2 ; 95 \% \mathrm{CI}: 0.93,1.58)$ and among couples who communicated sometimes $(\mathrm{aPR}=1.2 ; 95 \%$ CI: $1.03,1.44)$ compared to their counterparts who communicated once or twice. This finding is comparable with reports from Hartmann et al in Malawi, ${ }^{10}$ Matungulu et al in Lubumbashi, Democratic Republic of Congo, ${ }^{33}$ and in Prata et al in Luanda, Angola ${ }^{34}$ in which couples who frequently communicated about family planning were more likely to be current modern contraceptive users.
Spousal family planning communication has been found to be a significant predictor of contraceptive use in many studies. ${ }^{2,11,17,31}$ However, these studies defined communication in different ways. Some studies used all three dimensions of effective spousal family planning communication. ${ }^{19}$ Other studies have used discussion as the only measure of communication between husband and wife. ${ }^{2,12,17}$ Another difference between our analysis and previous research is that some other studies have defined spousal family planning communication more broadly. For example, Asa et $\mathrm{al}^{31}$ measured family planning communication among Nigerian couples using 30 items and creating a single composite variable. 
The prevalence of current modern contraceptive use among reproductive age women, i.e., 57.1\% (95\% CI, $0.53,3.39$ ) in our study is lower compared to the world average in 2019 in which $76 \%$ of currently married reproductive age women used modern contraceptive methods. ${ }^{35}$ This finding is higher than average for Africa in 2017 in which $32 \%$ of currently married reproductive age women used modern contraceptive methods. ${ }^{36}$ However, this finding is comparable with the national level average (50\%) of current modern contraceptive use among currently married reproductive age women in urban areas of Ethiopia. ${ }^{13}$ The current finding is higher than the finding in Dembia District of northwest Ethiopia in which $31.7 \%$ of currently married reproductive age women used modern contraceptives. ${ }^{15}$ This difference could be due to a study in Dembia District including study participants from rural areas.

The current study reveals that the most frequently used modern contraceptive method was implants $(38.2 \%)$ followed by injectables (37.4\%). This finding is comparable with the findings by Yimer and Modiba ${ }^{37}$ in which $51 \%$ of women used implants. However, the current finding is different from the findings in other studies ${ }^{11,13,38,39}$ in which injectables were the commonly used methods. This is indicating that women in Ethiopia are shifting from short-acting to long-acting family planning methods. However, the use of permanent family planning methods such as female and male sterilizations are very limited. The most commonly used modern contraceptive method among men was the condom. However, current use of male family planning methods $(2.3 \%)$ was very limited. This finding is lower compared to findings by Kassa et al ${ }^{40}$ in Debremarkos town in which $8.4 \%$ of men were current contraceptive users and to the finding by Shawano and Kura $^{41}$ in which $7.2 \%$ of men were found to be current contraceptive users.

Decreased current modern contraceptive use among older women $(\mathrm{aPR}=0.84 ; 95 \% \mathrm{CI}: 0.73,0.96)$ in our study is consistent with findings in Habyarimana and Ramroop in Rwanda ${ }^{42}$ and Alemayehu et al in Dabate Health and Demographic Surveillance System Site, northwest Ethiopia ${ }^{16}$ in which older age women were less likely to be current modern contraceptive users compared to their counterparts. Duration of current marriage was found to be significantly associated with current contraceptive use. Couples who stayed five to ten years in their current marriage were found 1.1 times more likely to be current contraceptive users compared to couples who stayed less than five years in their current marriage.

Religion was significantly associated with current modern contraceptive use. In this study followers of Christianity were 1.2 times more likely to be current contraceptive users compared to Muslims ( $\mathrm{P}=0.000 ; 95 \% \mathrm{CI}$ : $1.28,1.55)$. This finding is consistent with the finding in Nigeria in which contraceptive use was highest among Christian women compared to Muslim women. ${ }^{43}$ Similarly, a study in western Ethiopia corroborates this finding in which Muslim women were $65 \%$ less likely to utilize modern contraceptives compared to Orthodox Christian women. ${ }^{44}$ However, the current finding is different from the findings by Alvergne et $\mathrm{al}^{45}$ in the Arsi zone, Ethiopia in which Orthodox Christians were $78 \%$ less likely to be current contraceptive users compared to Muslims. The current finding is also different from the finding by Marrone et al in Ghana in which religion was not associated with current contraceptive use of females. ${ }^{46}$ This demonstrates the importance of enhancing enlightenment campaigns aimed at challenging the existing negative perceptions towards family planning and contraceptive use targeting reproductive age couples.

The prevalence ratio of current modern contraceptive use was higher among couples who had 3-4 children compared to couples who had 1-2 children (aPR $=1.2$; 95\% CI: 1.10,1.31). This finding is similar with reports in the Ethiopian Demographic and Health Survey, ${ }^{13}$ Alemayehu et al in Dabate Health and Demographic Surveillance System Site, northwest Ethiopia, ${ }^{16}$ and Abate and Tareke in Ethiopia. ${ }^{14}$ The current finding is also consistent with the finding in Nigeria in which, as the number of living children that women have increases, the odds of using contraceptive by the women increases. ${ }^{43}$ Couples who desired to have five and above children were found to be eleven percent less likely to be current contraceptive users compared to couples who desired one to four children.

Household monthly income was found to be significantly associated in both bivariate and multivariate analysis. Couples from households with an average monthly income between three thousand and six thousand Ethiopian Birr were 13\% less likely to be current contraceptive users compared to couples from households with average monthly income of three thousand and less.

Family planning approval by both husband and wife $(\mathrm{aPR}=4.7 ; 95 \% \mathrm{CI}: 2.19,10.01)$ and either by husband or wife $(\mathrm{aPR}=3.1 ; 95 \% \mathrm{CI}: 1.40,6.64)$ was significantly 
associated with current modern contraceptive use of women. This finding is consistent with the findings in Prata et al in Luanda, Angola, ${ }^{34}$ in Tuloro et al in Hossana Town, southern Ethiopia, ${ }^{11}$ and in Berhane et al in Angolela Tera District, Amhara Region, Ethiopia ${ }^{12}$ in which women's perception that their husbands/partners approve the use of family planning and husbands' approval of family planning were significantly associated with women's contraceptive use. In a study done in Ibadan, Nigeria partners' refusal to use family planning was a major obstacle to women's contraceptive use while the approval significantly increased contraceptive use. ${ }^{47}$

The significant association found between women's family planning counseling by health workers and their current modern contraceptive use $(\mathrm{aPR}=1.2 ; 95 \% \mathrm{CI}$ : 1.09 , 1.29) in this study is in line with a finding in Uttar Pradesh, India and a study in Ethiopia in which women who were counseled about family planning by health workers were more likely to be current contraceptive users compared to those women with no family planning counseling. ${ }^{48,49}$ In the current study family planning use decisions made by wives and jointly by husband and wife were better in leading women to the actual use of modern contraceptive methods compared to decisions made by husbands. Couples who were not supporters of large family size were 1.1 times more likely to be current modern contraceptive users compared to couples who support a large family size.

A limitation inherent to cross-sectional surveys is the difficulty to establish causal relationship. In our analysis it is impossible to identify whether spousal family planning communication causes contraceptive use except predicting contraceptive use. Spousal family planning communication may actually have occurred after contraceptive acceptance, given that the question on spousal family planning communication referred to the 12 month period before the survey. Another limitation to our study was the study covered only urban areas. We have no study participants from the rural part of eastern Ethiopia which limits its generalizability to rural parts of this region. As effective spousal family planning communication has emerged as an important predictor of family planning use, we recommend future research to include not only the three dimensions of family planning communication but also other matters in the family that require communication between spouses, for example, decisions about education of children, financial matters and food purchases, among others.

\section{Conclusion}

In conclusion, about half of the study participants were current modern contraceptive users. Effective spousal family planning communication was significantly associated with current modern contraceptive use of couples, even controlling for other socio-economic and demographic variables. Hence, the study result implies that policies and programs aimed at promoting family planning could benefit from productive spousal family planning communication.

\section{Recommendations}

This study highlights the critical role played by spousal family planning communication in the use of contraception, even when controlling for other predictor variables of contraceptive use. Thus, policies and programs aimed at increasing contraceptive prevalence should properly address the importance of spousal communication about family planning in their programs. Interventions made by governmental and nongovernmental organizations to promote family planning should integrate men into family planning programs. Programs facilitating and enhancing couples communication skills and encouraging them to communicate need to be promoted.

When both husband and wife approve family planning, their contraceptive use was higher even compared to couples of which either husband or wife approves it. This highlights the need to encourage husbands to approve family planning in relation to contraceptive utilization of their wives. Moreover, family planning use decisions made by wives and jointly by husband and wife were better in leading to contraceptive use than decisions made by husbands. It is therefore important to incorporate men in contraceptive counseling to improve couples' contraceptive use and ultimately ensure reduction in maternal mortality by preventing high risk pregnancies as well as achieve a healthy mother, family and society. In this study the proportion of men visited by house to house visits of health extension workers and their proportion counseled about family planning at health institution was very low. This should be improved to promote the involvement of men in family planning communication and decision-making so that to increase the prevalence of contraceptive use in the study area. Women who were visited by house to house visits of health extension workers and who were counseled about family planning by health workers were better contraceptive users compared to women who never visited and were not counseled. Thus, 
the health extension program should be strengthened so that those women who were not reached could be reached for counseling by health workers.

\section{Abbreviations}

CI, confidence interval; HDSS, Health and Demographic Surveillance System; FP, family planning; aPR, adjusted prevalence ratio; $\mathrm{RC}$, reference category; $\mathrm{TV}$, television; $\mathrm{P}$, P-value (or significance level); HW, health workers.

\section{Data Sharing Statement}

Data analyzed and materials used for this article are available with the corresponding author and can be obtained on request.

\section{Ethical Approval and Consent}

Ethical approval was secured from Institutional Health Research Ethics Review Committee of College of Health and Medical Sciences, Haramaya University. Informed, voluntary, written and signed consent was obtained from the study participants.

\section{Acknowledgments}

We would like to acknowledge Addis Continental Institute of Public Health for technical support. Our thanks also extends to the study participants and data collectors for their kind cooperation.

\section{Author Contributions}

All authors made a significant contribution to the work reported, whether that is in the conception, study design, execution, acquisition of data, analysis and interpretation, or in all these areas; took part in drafting, revising and critically reviewing the article; gave final approval of the version to be published; have agreed on the journal to which the article has been submitted; and agree to be accountable for all aspects of the work.

\section{Funding}

This research has been funded by Haramaya University.

\section{Disclosure}

The authors declared that they have no conflicts of interest for this work.

\section{References}

1. Islam MA, Padmadas SS, Smith PWF. Understanding family planning communication between husbands and wives: a multilevel analysis of wives "responses from the Bangladesh DHS. Genus. 2010;66(1):1-15.
2. Islam MS, Alam MS, Hasan MM. Inter-spousal communication on family planning and its effect on contraceptive use and method choice in Bangladesh. Asian Soc Sci. 2014;10:2.

3. Sharan M, Valente TW. Spousal communication and family planning adoption: effects of radio drama serial in Nepal. Int Fam Plan Perspect. 2002;28(1):16-25. doi:10.2307/3088271

4. Link CF. Spousal communication and contraceptive use in rural Nepal: an event history analysis. Stud Fam Plann. 2012;42 (2):83-92. doi:10.1111/j.1728-4465.2011.00268.x

5. Behera J, Sarkar A, Mehra S, Sharma P, Mishra SK. Encourage young married women (15-24 years) to improve intra-spousal communication and contraceptive usage through community based intervention package in rural India. J Contracept Stud. 2016;1:4.

6. Acharya R, Sureender S. Inter-spouse communication, contraceptive use and family size: relationship examined in Bihar and Tamil Nadu. J Fam Welf. 1996;42(4):5-11.

7. Kamal N. Inter-spousal communication on family planning as a determinant of the use of modern contraception in Bangladesh. J Fam Welfare. 1999;45(1):31-43.

8. Mesfin G. The role of men in fertility and family planning program in Tigray region. Ethiop J Health Dev. 2002;16(3):247-255.

9. Abreham W, Adamu A, Deressa D. The involvement of men in family planning: an application of transtheoretical model in Wolaita Sodo Town, Southern Ethiopia. Asian J Med Sci. 2010;2(2):44-50.

10. Hartmann M, Gills K, Shattuck D, Kerner B, Guest G. Changes in couples' communication as a result of a male-involvement family planning intervention. $J$ Health Commun. 2012:17(7);1-18.

11. Tuloro T, Deressa W, Ali A, Davey G. The role of men in contraceptive use and fertility preference in Hossana Town, Southern Ethiopia. Ethiop J Health Dev. 2006;20(3):152-159.

12. Berhane A, Biadeglign S, Amberbir A, Morankar S, Berhane A, Deribe K. Men's knowledge and spousal communication about modern family planning methods in Ethiopia. Afr J Reprod Health. 2011;15 (4):24-32.

13. Central Statistical Agency (CSA) [Ethiopia] and ICF International. Ethiopia Demographic and Health Survey 2016. Addis Ababa, Ethiopia, and Rockville, Maryland, USA: CSA and ICF; 2016.

14. Abate MG, Tareke AA. Individual and community level associates of contraceptive use in Ethiopia: a multilevel mixed effects analysis. Arch Public Health. 2019;77(46). doi:10.1186/s13690-019-0371-z

15. Debebe S, Limeneh M, Biadgo B. Modern contraceptive methods utilization and associated factors among reproductive age women in rural Dembia District, northwest Ethiopia: community based cross sectional study. Int $J$ Reprod Biomed. 2017;15:367-374. doi:10.29252/ijrm.15.6.367

16. Alemayehu GA, Fekadu A, Yitayal M, et al. Prevalence and determinants of contraceptive utilization among married women at Dabat health and demographic surveillance system site, northwest Ethiopia. BMC Womens Health. 2018;18(1):118. doi:10.1186/s12905-018-0611-3

17. Helamo D, Tessema F, Doyore F. Assessment of husband-wife communication and practice of contraceptives in Angecha Woreda, Kembata Tembaro zone, South Ethiopia: a cross sectional study. Reprod Syst Sex Disord. 2014;3(3):134.

18. Tilahun T, Coene G, Temmerman M, Degomme O. Couple based family planning education: changes in male involvement and contraceptive use among married couples in Jimma Zone, Ethiopia. BMC Public Health. 2015;15:682. doi:10.1186/s12889-015-2057-y

19. Lasee A, Becker S. Husband-wife communication about family planning and contraceptive use in Kenya. Int Fam Plan Perspect. 1997;23:15-20\& 33.

20. BOFED, Harari Regional State. Demographic and Socio-Economic Profile of Harari Regional State. Harar, Ethiopia: unpublished document; 2011.

21. Central Statistical Agency (CSA) [Ethiopia] and ICF International. Population Projections for Ethiopia: 2007-2037. Addis Ababa, Ethiopia; 2013. 
22. INDEPTH Data Repository. Harar urban HDSS INDEPTH core dataset 2012-2016 (release 2018). 2018. Available from: http:// indepth-ishare.org.md-in-71.hostgatorwebservers.com/index.php. Accessed January 18, 2021.

23. Assefa N, Semahegn A. Fertility is below replacement in Harar Health and Demographic Surveillance System (Harar HDSS), Harar town, Eastern Ethiopia. Fertil Res Pract. 2016;2:10. doi:10.1186/s40738-0160023-8

24. Central Statistical Agency (CSA) [Ethiopia] and ICF International. Ethiopia Demographic and Health Survey 2011. Addis Ababa, Ethiopia and Calverton, Maryland, USA: Central Statistical Agency and ICF International; 2012.

25. Gebresellasie T, Mishra V. Spousal Agreement on Family Planning in Sub-Saharan Africa: DHS Analytical Studies No. 11. Calverton, Maryland, USA; 2007. Available from: www://dhsprogram.com/pub lications/publication-as11-analytical-studies.cfm.

26. Zhang J, Yu KF. What's the relative risk? A method of correcting the odds ratio in cohort studies of common outcomes. JAMA. 1998;280:1690-1691. doi:10.1001/jama.280.19.1690

27. Yelland LN, Salter AB, Ryan P. Performance of the modified poisson regression approach for estimating relative risks from clustered prospective data. Am J Epidemiol. 2011;174:8. doi:10.1093/aje/kwr183

28. Zou G. A Modified Poisson Regression approach to prospective studies with binary data. Am J Epidemiol. 2004;159:7. doi:10.1093/aje/kwh090

29. Wacholder S. Binomial regression in GLIM: estimating risk ratios and risk differences. Am J Epidemiol. 1986;123(1):174-184. doi:10.1093/oxfordjournals.aje.a114212

30. Tilahun T. Marital dynamics in family planning: the role of couple interaction in Jimma zone, Southwest Ethiopia. Doctoral thesis submitted to the Faculty of Medicine and Health Sciences Ghent University. Available from: https://biblio.ugent.be/publication/ 5784759/file/5784760.pdf. Accessed January 18, 2021. 2014.

31. Asa UA, Nkan VV, Okoro GI. Spousal communication and contraceptive use among married couples in rural areas of Akwa Ibom State, Nigeria. J Educ Soc Res. 2018;8:1. doi:10.2478/jesr-2018-0006

32. Akwenabuaye UV, Kalu OO, Anake UM, Happiness OR. Family planning behaviors and decision making among couples in cross river state, Nigeria. Int J Learn Dev. 2013;3:1. doi:10.5296/ijld.v3i1.3146

33. Matungulu MC, Ntambue MA, Ilunga KS, Musau NA, Ilunga MT, Malonga KF. Factors associated with the use of modern contraceptive methods by women in Marital union in the city of Lubumbashi, Democratic Republic of the Congo: cross-sectional study. Austin $J$ Womens Health. 2017;4:1.

34. Prata N, Bell S, Fraser A, Carvalho A, Neves I, Andrade BN. Partner support for family planning and modern contraceptive use in Luanda, Angola. Afr J Reprod Health. 2017;23(1):35-48. doi:10.29063/ajrh2017/ v21i2.5

35. United Nations, Department of Economic and Social Affairs, Population Division. Contraceptive use by method 2019: data booklet (ST/ESA/SER.A/435). 2019.

36. United Nations, Department of Economic and Social Affairs, Population Division. World family planning 2017 - highlights (ST/ ESA/SER.A/414). 2017.

Open Access Journal of Contraception

\section{Publish your work in this journal}

Open Access Journal of Contraception is an international, peerreviewed, open access, online journal, publishing original research, reports, reviews and commentaries on all areas of contraception. In addition to clinical research, demographics and health-related aspects, the journal welcomes new findings in animal and preclinical
37. Yimer AS, Modiba LM. Modern contraceptive methods knowledge and practice among blind and deaf women in Ethiopia: a cross-sectional survey. BMC Womens Health. 2019;19(151). doi:10.1186/s12905-019-0850-y

38. Medhanyie AA, Desta A, Alemayehu M, et al. Factors associated with contraceptive use in Tigray, North Ethiopia. Reprod Health. 2017;14(27). doi:10.1186/s12978-017-0281-x

39. Hagos H, Tiruneh D, Necho W, Biru S. Postpartum intra-uterine contraceptive device utilization among mothers who delivered at Debre Tabor general Hospital: cross-Sectional study design. Int J Family Community Med. 2020;4(5):139-144.

40. Kassa M, Abajobir AA, Gedefaw M. Level of male involvement and associated factors in family planning services utilization among married men in Debremarkos town, Northwest Ethiopia. BMC Int Health Hum Rights. 2014;14:33. doi:10.1186/s12914-014-0033-8

41. Shaweno T, Kura Z. Determinants of modern contraceptive use among sexually active men in Ethiopia; using EDHS 2016 national survey. Contracept Reprod Med. 2020;5(5). doi:10.1186/s40834-02000108-7

42. Habyarimana F, Ramroop S. The analysis of socio-economic and demographic factors associated with contraceptive use among married women of reproductive age in Rwanda. Open Public Health J. 2018;11:348-359. doi:10.2174/1874944501811010348

43. Obasohan PE. Religion, ethnicity and contraceptive use among reproductive age women in Nigeria. Int $J$ MCH AIDS. 2015;3(1):63-73.

44. Tigabu S, Demelew T, Seid A, Sime B, Manyazewal T. Socioeconomic and religious differentials in contraceptive uptake in western Ethiopia: a mixed-methods phenomenological study. $B M C$ Womens Health. 2018;18(1):85. doi:10.1186/s12905-018-0580-6

45. Alvergne A, Ojo O, Ogbeye GB, Gibson M, Gurmu E, Mace R. Social transmission and the spread of modern contraception in Rural Ethiopia. PLoS One. 2011;6:7. doi:10.1371/annotation/d4ace6be2089-47e8-86b2-42d04189324a

46. Marrone G, Abdul-Rahman L, Coninck ZD, Johansson A. Predictors of contraceptive use among female adolescents in Ghana. Afr J Reprod Health. 2014;18(1):102-109.

47. Ndikom CM. Women's choice, satisfaction, and compliance with contraceptive methods in selected hospitals of Ibadan, Nigeria. J Midwifery Reprod Health. 2018;6(1):1113-1121.

48. Dehingia N, Dixit A, Averbach S, et al. Family planning counseling and its association with modern contraceptive use, initiation and continuation in rural Uttar Pradesh, India. Reprod Health. 2019;16:178. doi:10.1186/s12978-019-0844-0

49. Hrusa G, Spigt M, Dejene T, Shiferaw S. Quality of family planning counseling in Ethiopia: trends and determinants of information received by female modern contraceptive users, evidence from national survey data, (2014-2018). PLoS One. 2020;15(2). doi:10.1371/journal.pone. 0228714 studies relating to understanding the biological mechanisms and practical development of new contraceptive agents. The manuscript management system is completely online and includes a very quick and fair peer-review system. Visit http://www.dovepress.com/testimonials. php to read real quotes from published authors.

\section{Dovepress}

